して利用されてきた. 折しも, 人口増加, 地球温暖化に 加え, 石油代替品としての競合から派生する食糧不足が 人類の未来に大きな影を落としている. サツマイモは, アヤムラサキに代表される機能性食品素材のみならず, 厳しい環境でも容易に栽培できるエコ作物として, 近い 将来健康や環境を守る救世主となるかもしれない.

1) A. Scalbert \& G. Williamson : J. Nutr., 130, 2073S (2000).

2) 宮澤陽夫, 仲川清隆, 浅井 明: 化学と生物, 38, 104 (2000).

3) I. Suda, T. Oki, M. Masuda, Y. Nishiba, S. Furuta, K.
Matsugano, K. Sugita \& N. Terahara:J. Agric. Food. Chem., 50, 1672 (2002).

4) K. Harada, M. Kano, T. Takayanagi, O. Yamakawa \& F. Ishikawa : Biosci. Biotechnol. Biochem., 68, 1500 (2004).

5) M. Kano, T. Takayanagi, K. Harada, K. Makino \& F. Ishikawa : Biosci. Biotechnol. Biochem., 69, 979 (2005).

6) I. Suda, F. Ishikawa, M. Hatakeyama, M. Miyawaki, T. Kubo, K. Hirano, A. Ito, O. Yamakawa \& S. Horiuchi : Eur. J. Clin. Nutr., 62, 60 (2008).

（狩野光芳, 原田勝寿, 株式会社ヤクルト本社中央研究 所)

\title{
○|トランス脂肪酸の国内外における規制状況 心臓血管系疾患のリスクを高める食事因子にどう対処するか
}

トランス脂肪酸（以下, トランス酸）は，動脈硬化， 冠動脈, 心疾患のリスクを高める食事因子であることが 欧米での疫学調査から明らかとなった。これらの結果に 基づき, 食品中トランス酸含有量の表示義務化や摂取量 の勧告などが各国で行なわれている。こうした諸外国の 対応を受けて, わが国でもトランス酸への関心が高まっ ている。ここでは, トランス酸の概要, 心疾患との相関 性, 外国におけるトランス酸表示, 国内におけるトラン ス酸事情などについて紹介する.

脂肪酸は, 飽和脂肪酸と不飽和脂肪酸に大きく分類さ れる。不飽和脂肪酸の炭素間結合様式にはシス型とトラ ンス型があり, 炭素に結びつく水素の向きが同じ向きの ものがシス型, 互い違いになっているものをトランス型 という。トランス酸は, 不飽和脂肪酸のうち二重結合の 立体配位がトランス型になっているものの総称であ $ろ^{(1)}$.

トランス酸の多くは, 水素添加による加工油脂の製造 工程で生じる。トランス酸を含む代表的な加工油脂とし てマーガリン類やショートニングあるいは業務用調理油 などがある。この他にも反㫚動物の肉や乳あるいは脂肪 中に 5 (重量％）前後のトランス酸が含まれている.

油脂加工における水素添加とは, 不飽和脂肪酸の二重 結合部位に水素を添加する操作をいう。水素添加された 油脂は融点が上昇し硬化度が増すため, 目的に応じた物 性を示す油脂が得られる(2). 心疾患リスク因子との関連 が指摘されているトランス酸は, 反㫚動物に存在するト ランス酸よりも加工油脂の製造により生じる非天然型卜 ランス酸である.
トランス酸の国際的な定義や摂取に関して, WHO （世界保健機関）と FAO（食糧農業機関）が共同で設置 している国際食品規格の作成を行なう専門の委員会であ る CODEX 委員会 (The Codex Alimentarius Commission : CODEX) では,「トランス脂肪酸とは, 少なくとも 1 個のメチレン基によりさえぎられた, 非共役型の炭素炭素の二重結合をもつ，トランス配位の 1 価不飽和脂肪 酸および多価不飽和脂肪酸のすべての幾何異性体であ る」と定義している (2005 年 5 月 ${ }^{(3)}$.

トランス酸摂取が心疾患リスク因子によ゙のような影響

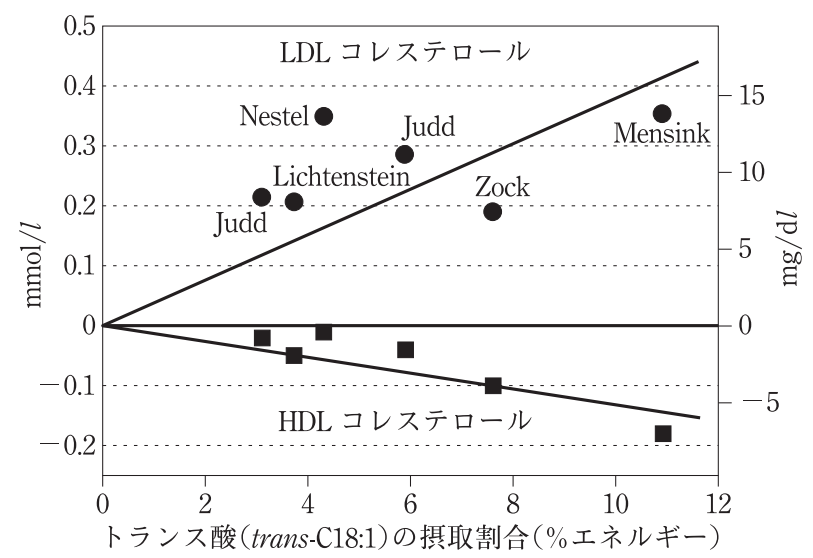

図 1 ・トランス酸摂取量とリポタンパク質コレステロール濃 度の相関性 (P. L. Zock et al. : Can. J. Physiol. Pharmacol., 75, 211 (1997))

トランス酸摂取の増加に伴い，悪玉 (LDL) コレステロール濃度 の上昇と善玉 (HDL) コレステロール濃度の低下を示すことが疫 学調査から明らかとなった. トランス酸過剩摂取に伴うコレス テロール濃度の変化は，心疾患のリスクを一層高めることを意 味する. 
を及ぼすかを示す疫学調査の結果が Zock らによって示 された。この中で，ヒトにおけるトランス酸摂取量の増 加とリポタンパク質コレステロール濃度変化の相関性が 明らかにされた（図 1) ${ }^{(4)}$.

こうしたデータや疫学調査の結果を踏まえて, CODEX 委員会の下で食事や栄養に関する科学的な評価を 行なう WHO/FAO 食事, 栄養および慢性疾患予防に関 する合同専門家会合では, 心臓血管系の健康に関して, 食事からのトランス酸の摂取を極力低く抑えるべきであ り, トランス酸の摂取量を一日当たり総エネルギー摂取 量の $1 \%$ （約 $2 \mathrm{~g}$ ）未満とするよう勧告している。 また, アメリカ食品医薬品安全局 (FDA) も同様の掑取量を勧 告している.

トランス酸の表示や規制に関してもCODEX 委員会 で検討されているが，これまでのところ表示の義務化に 至らず，各国個別に対応することとなっている．アメリ カでは, これまでの疫学調査研究の結果から, 心疾患の リスクを低減する目的で 2006 年 1 月 1 日より加工食品 に含まれるトランス酸量の表示を義務化した。一日摂取 量が $0.5 \mathrm{~g}$ 以上のサプリメントにも適応される.今回の 表示では，水素添加によって生じたトランス酸と反㱀動 物に含まれるトランス酸を含めた值が表示されるが， 1 サービング*1 当たり $0.5 \mathrm{~g}$ 以下であればトランス酸フ リーとして認められる。

EU では 2004 年に欧州食品安全機関 (EFSA) が，食品 中トランス酸のヒトへの健康影響に関する意見書を提出 し，トランス酸は心疾患発症と正の相関を示すことを示 唆している。しかし，これまでのところ統一的な表示の 規制に至っていない.

デンマークでは, 2004 年 1 月より国内で販売する加工 食品の油脂中トランス酸含有量を $2 \%$ （重量比）までに 制限している (動物由来のトランス酸は除く). したがっ て，2\%以上のトランス酸を含む製品は販売できない.

アジアでも韓国と台湾で表示が行なわれている，韓国 では 2007 年 12 月にトランス酸の表示義務化と 2010 年 までに摂取量の低減化を目標に取り組んでいる。 また台 湾では 2008 年 1 月に飽和脂肪酸とトランス酸の表示義 務化を始めた. $100 \mathrm{~g}$ 当たり $0.3 \mathrm{~g}$ 以下はトランス酸フ リーとなる。

\footnotetext{
*1米国食事指針における 1 回の摂取量または 1 皿分を示す。

*2一日に摂取する総エネルギーに占める割合
}

一方，オーストラリアやニュージーランドでは，トラ ンス酸の摂取量が少なく，現在のところ表示などの規制 は予定されていない.

国内では, 2007 年 6 月に食品安全委員会からトランス 酸撕取に関するファクトシートが示された ${ }^{(5)}$.この中で, 加工油脂生産量加ら消費量を推定する方法に加えて, 国 民健康・栄養調査の結果からトランス酸摂取量を積み上 げ式に算出する方法が採用され, 日本人におけるトラン ス酸の摂取量が $0.3 \sim 0.6$ エネルギー $\%$ *2 であることが示 された.これらの值はいずれも WHO やFDA が勧告し ている摂取レベルよりも低い值となっている。これまで のところ, 国内においてトランス酸の表示義務化や摂取 量勧告などは予定されていない.

おそらくトランス酸の過剰摂取を行なえば心疾患のリ スクを増加させることは間違いないであろう。しかし， 日本人におけるトランス酸の健康影響評価を行なうに は，現状のトランス酸摂取量と疾病との相関性を明らか にすることや，他の食事因子による影響を考慮した評価 が重要となる。事実, 食品安全委員会でも「健康保護の 観点から，今後とも，日本人（または日本での）の摂取 量や各摂取レベルにおける健康への影響などに関する国 内外の新たな知見を蓄積していくことが必要」との見解 が示され，日本人におけるトランス酸の健康影響を評価 するための情報が十分に伴っていない状況と考えられ る。しかし，現在日本人の食を取り巻く環境や嗜好性は 欧米化の傾向を示し，加工油脂を用いて調理加工された 食品を摂取する機会が多い。このような食環境は，容易 にトランス酸の摂取量が増加する環境でもあり, 日常の 食生活においてトランス酸を含めた油脂類の過剩摂取に 注意を払う必要がある。

1) P. M. Kris-Etherton : Am. J. Clin. Nutr., 62, 655S (1995).

2) 神村義則監修：“新訂版・食用油脂入門”, 日本食糧新聞 社, 2005, p. 135.

3) http://www.codexalimentarius.net/download/report /627/al28_26e.pdf

4) P. L. Zock \& M. B. Katan : Can. J. Physiol. Pharmacol., 75, 211 (1997).

5) http://www.fsc.go.jp/sonota/factsheets.html

（永田純一, 山田和彦, 独立行政法人国立健康・栄養研 究所) 